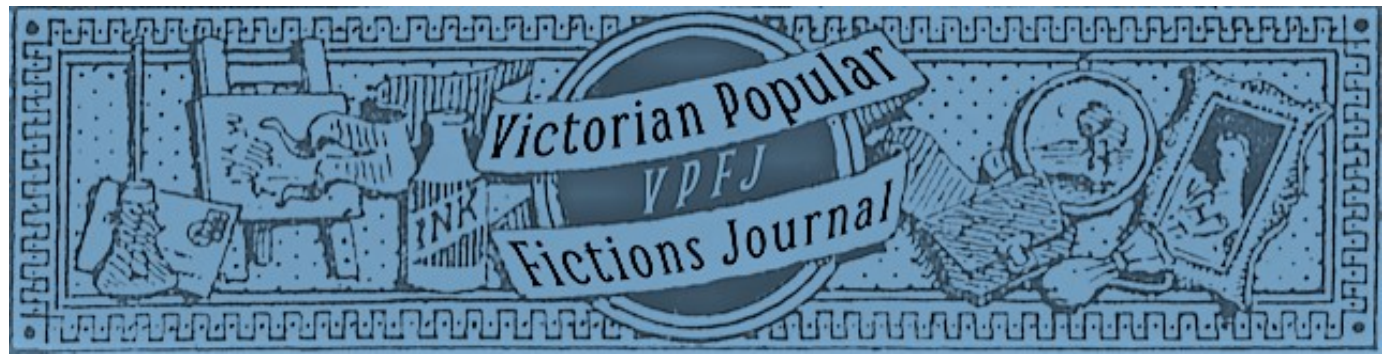

\title{
Spaces of Mystery, Knowledge and Truth in Early Russian Crime Fiction: Semyon Panov's Three Courts, or Murder during the Ball (1876)
}

\section{Claire Whitehead}

\begin{abstract}
This article examines the representation of space and place in a work of nineteenth-century Russian crime fiction. It argues that crime fiction generally offers fertile ground for an interrogation of the representation of space as a means better to understand ideological and aesthetic preoccupations. Appreciation of nineteenth-century Russian crime fiction remains limited in both critical and public circles, and so a focus on the exploitation of space in a work from this particular national tradition will complement existing critical work on this topic relating to other geographical regions and historical periods. This article uses Semyon Panov's 1876 novel, Three Courts, or Murder During the Ball, as its test case both because it is archetypical of generic practice in Russia in the late nineteenth century to some extent, but also because its representation of space is particularly well-developed. Space in Panov's Three Courts is examined from a number of different angles here: its use of a setting in an unnamed provincial town; its location in a labyrinthine family mansion which gestures towards the locked-door mystery typical of both this and other genres; its exploitation of the architectural features of the corridor and of a glass ceiling and windows. The article argues that Panov uses all of these spatial elements to interrogate and problematise issues related to the authority of the figure of the detective, the access to the "truth" and the resolution of the criminal mystery.
\end{abstract}

\section{Key words}

Russian crime fiction; nineteenth century; Semyon Panov; space; provincial town; corridor; glass.

Date of Acceptance: 23 December 2019

Date of Publication: 31 December 2019

Double Blind Peer Reviewed

\section{Recommended Citation:}

Whitehead, Claire. "Spaces of Mystery, Knowledge and Truth in Early Russian Crime Fiction: Semyon Panov's Three Courts, or Murder during the Ball (1876)." Victorian Popular Fictions, 1.2: 110-122. ISSN: 2632-4253. DOI: https://doi.org/10.46911/CULA1939

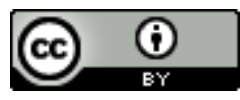

This work is licensed under a Creative Commons Attribution 4.0 International License. 


\title{
Spaces of Mystery, Knowledge and Truth in Early Russian Crime Fiction: Semyon Panov's Three Courts, or Murder during the Ball (1876)
}

\author{
Claire Whitehead
}

\section{Introduction}

Ever since the fall of the Soviet Union in 1991, crime fiction has dominated the Russian literary landscape. The relaxation of censorship laws and the liberalisation of commercial conditions which accompanied the totalitarian regime's disintegration led initially to an influx of translated crime thrillers and detective stories from the West. Fairly swiftly, however, these were joined and then overtaken by indigenous production to the extent that, nowadays, novels by authors such as Daria Dontsova, Aleksandra Marinina and Boris Akunin frequently top Russia's bestseller lists. ${ }^{1}$ There is a temptation amongst some commentators to see this contemporary crime fiction boom as a unique historical phenomenon; however, the genre has a much longer history in Russia, reaching back to the late Imperial era in the second half of the nineteenth century. Indeed, the similarities between the conditions that led to the genre's popularity in the post-Soviet era and those that pertained in the early $1860 \mathrm{~s}$ when the genre was born in Russia are striking. The country responded to its defeat in the Crimean War of 1856 with a programme of modernisation and liberalisation that comprised the Emancipation of the Serfs in 1861, educational reform that considerably increased the population's literacy rate and, equally crucially for the development of detective fiction, fundamental changes to its outmoded judicial system, including the introduction of the new figure of the judicial investigator. ${ }^{2}$ These various changes, allied with a curbing of state censorship, prepared the ground for the birth of Russian crime fiction in the early 1860s; however, knowledge of the genre's existence during this period and its particularities remains limited, even within Russia.

If knowledge about the early years of Russian crime fiction does exist, it tends to be dominated by the figure of Fedor Dostoevskii, whose novel Crime and Punishment was published in serialised form in 1866. In actuality, however, the development of the genre in Russia in the 1860s and 1870s owes as much if not more to a host of marginalised figures from the country's literary history. Forgotten writers such as Nikolai Sokolovskii, Nikolai

\footnotetext{
${ }^{1}$ Between 1995 and 2003, Eksmo published more than 27 million copies of Dontsova's crime novels whilst Marinina had sold some 32 million copies by the same year. Akunin's various series of detective novels are equally popular and have been translated into English by Andrew Bromfield.

2 As Jeffrey Brooks has demonstrated in When Russia Learned to Read (2003), developments in literacy and primary schooling as well as the diversification in publishing practices which followed the Emancipation Act of 1861 led to an explosion in the production of fiction featuring crime, detectives, adventure and bandits in the final decades of the nineteenth century. The judicial reforms in Russia, which also included the publication of new Court Statutes in 1864, rendered the judiciary independent of the administrative framework of the state, introduced jury trials, and had as one of their primary aims "greater professionalism, legality and objectivity in the investigatory stages of the case" (Burnham 2002: 1232).
} 
Timofeev and Aleksandr Shkliarevskii, to name but a few, wrote numerous works of crime fiction that were enormously popular with the contemporary readership and that deserve much greater public attention nowadays. ${ }^{3}$ Many of these works are intriguing and sophisticated examples of the genre, and an appreciation of their construction and preoccupations can complement and extend our understanding of better-known examples from other national traditions. The development of such an appreciation is, at least in part, one of the aims of the present essay. As I have demonstrated elsewhere, one might examine early Russian crime fiction from a variety of perspectives, including genre, narrative voice, temporal organisation and intertextuality. ${ }^{4}$ However, what the discussion offered here proves is that early Russian crime fiction also extends significant potential in terms of a consideration of space and spatial representation. As the collection of essays in this Special Issue makes abundantly clear, a cross-cultural examination of the various issues related to space in popular fiction can produce stimulating results. In the field of crime fiction studies specifically, the role of geographical setting and mapping has gained traction over recent years, with valuable work done on the potential of these elements to tell us, amongst other things, about "the ways in which power and authority are spatialised" (Schmid 2012: 9). Moreover, as David Schmid goes on to argue, "studying representations of space in crime fiction can give us a way of contesting a characterisation of the genre that dismisses it as a closed, formal system" (Schmid 2012: 10-11). The present article builds on such pre-existing scholarship by extending the critical focus on the exploitation of space in crime fiction to include the neglected area of Russian practice of the genre in the early years of its development. As will become evident in what follows, a reading of the representation of space provides a means to interrogate issues such as the characterisation of the figure of the detective, the epistemological challenge entailed in trying to uncover the "truth" of the crime, and the networks of power and authority (including social class) that exist around that truth. However, whilst the insights offered here emanate from a reading of early Russian crime fiction, they are equally applicable to many other national and historical instances of the genre.

For the purposes of the current article, the spotlight will be directed towards one particular example of early Russian crime fiction: Semyon Panov's 1876 novel Three Courts, or Murder during the Ball: The Tale of a Judicial Investigator in Two Parts. Panov is an unfamiliar name even to experts in nineteenth-century Russian literature, but he wrote five, high-quality, crime novels during the 1870s. In many respects, Three Courts is an archetype of much early Russian crime fiction: the novel features as its main protagonist a judicial investigator, a relatively new position in the Russian legal landscape of the time after its introduction in 1860; it showcases narrative elements typical of the realist mode in which all Russian crime fiction was written; it demonstrates an implicit knowledge of foreign precursors; and its publication date of 1876 coincides with the shift in the Russian genre away from the "whydunit" model showcased by the very earliest examples, and towards the

${ }^{3}$ In his study From Bova to Bal'mont and Other Works on the Historical Sociology of Russian Literature, Avram Reitblat demonstrates that many works of crime fiction published in the second half of the nineteenth century featured amongst the most-read works of their respective year of publication. Such works include Sokolovskii's Prison and Life: From the Notes of an Investigator in 1866, Timofeev's Notes of an Investigator in 1872 and Shkliarevskii's Collected Works in 1881, as well as Dostoevskii's Crime and Punishment.

${ }^{4}$ See my 2018 monograph, The Poetics of Early Russian Crime Fiction 1860-1917: Deciphering Stories of Detection. 
"whodunit" type used here and in almost all subsequent Russian crime stories. ${ }^{5}$ Whilst the ends to which space is exploited in Panov's novel cannot be said to be unique in the context of early Russian crime fiction, the decision to use Three Courts as the test case in this article is predicated on the fact that the emphasis that it places on the role of space is arguably more developed than in many other works of the time. ${ }^{6}$

Three Courts recounts the case surrounding the murder of Elena Ruslanova, who has her throat slit and her diamond tiara stolen during the ball held at her family's mansion to celebrate her engagement. One of the immediately striking elements of Panov's choice of crime scene and occasion is the fact that, despite the murder taking place during a ball at which 227 guests are in attendance, its location clearly suggests elements of the locked-room mystery so popular in detective fiction. Elena is murdered in a dressing room in the heart of the family mansion, to which all doors are locked, and into and out of which no one was seen either entering or leaving. The trope of the locked-room mystery in crime fiction dates back at least as far as the publication of Edgar Allan Poe's foundational story, "The Murders in the Rue Morgue," in 1841. It is this story that has been exploited by critics to argue for the essentially self-referential, closed nature of the genre. However, crucially, as has been pointed out, a careful consideration of that particular work demonstrates that the L'Esplanaye apartment is not, in fact, an entirely closed space, but only appears to be so at first sight. Panov's Three Courts similarly plays with the juxtaposition between, and the misapprehension of, the open / closed opposition to reflect on the novel's generic status and, especially, its relationship to systems of knowledge. ${ }^{7}$ Beyond that, the novel uses the mansion's labyrinthine layout, its location in a provincial Russian town, and specific architectural features (notably the corridor and windows and a glass ceiling) to comment implicitly on the detective's quest for knowledge about the crime. The ambiguity surrounding the depiction of these spatial elements appears to offer to the detective and the reader the possibility of arriving at the truth whilst simultaneously problematising the existence and the nature of that truth.

\section{The Provincial Site of Crime}

Three Courts is somewhat unusual for early Russian crime fiction in being set in a provincial town - a place known throughout only as N. Although this is a location shared with Panov's other 1876 novel, From the Life of a Provincial Town, it is distinct both from his three other novels, and much of Russian crime fiction from the same or an earlier period, which are more distinctly rural in their setting. ${ }^{8}$ In such early works, whilst a provincial town might figure as

\footnotetext{
5 As Louise McReynolds discusses in her 2006 article, early Russian crime fiction frequently contained little mystery about the identity of the culprit, preferring to have investigators concentrate on the question of "why" a crime had been committed (McReynolds 2006: 394).

${ }^{6}$ Panov's novel is also the focus of a Knowledge Exchange and Impact project ("Lost Detectives"), funded by the University of St Andrews, that I am currently working on with the author-illustrator, Carol Adlam. I am very grateful to Carol for the opportunity to discuss and develop many of the ideas related to space that are elaborated in this article.

${ }^{7}$ Although it cannot be proved definitively that Panov had read Poe's story, it is quite likely given the translation and publication date in Russia. Poe's story first appeared in Russian translation in two volumes of the popular journal, Son of the Fatherland, in March 1857 under the title "A Mysterious Murder." Although this first translation was published anonymously, Poe's story appeared in a number of other Russian translations before the publication of Panov's Three Courts in 1876.

${ }^{8}$ For example, Panov's novel The Harvest Gathering from 1872 is set in the village of Malyi Neriushev, while Sokolovskii's Prison and Life, Petr Stepanov's The Innocent and the Guilty: Notes
} 
the location of the investigator's lodgings, it does not function as the main site of the crimes committed or the investigations conducted. Equally, for early Russian crime fiction, the urban, St Petersburg setting of Dostoevskii's Crime and Punishment is anomalous and does not establish itself as the generic norm until later in the 1870 s and 1880 s. The motif of the provincial town of $\mathrm{N}$. has been a common one in Russian realist fiction of all genres since the nineteenth century and at least the time of Nikolai Gogol's 1842 novel Dead Souls. ${ }^{9}$ Following Gogol, authors such as Nikolai Leskov, Ivan Turgenev, Dostoevskii and Natalia Khvoshchinskaia "all imagine nameless towns that are said to resemble myriad other such towns, each embodying the often horrific pettiness of provincial life" (Lounsbery 2004). The choice of such a setting for a work of crime fiction, specifically, is significant in epistemological terms: by making a town that is supposedly indistinguishable from so many others the location of a crime whose nature is grimly unique complicates assumptions around familiarity and difference; at the same time, this combination of genre and setting creates an interesting set of expectations in the reader's mind with regard to questions of knowledge. As Anne Lounsbery argues, with reference to the provincial town of N. in Dead Souls, the novel

repeatedly suggests that any provincial city can stand in for any other; in fact, almost no trait is attributed to N. that is not also attributed to "all provincial cities." Such uniformity suggests that any provincial place, even an unfamiliar one, is in effect always already known, since the provincial admits of no real variation, no individuality, no change.

(Lounsbery 2004)

What Panov does in Three Courts, however, is to exploit productively the tension between the reader's expectations of the known-ness or knowability of the provincial town of N., and the mystery surrounding the murder of Elena Ruslanova and its perpetrator(s). By using this setting for his crime novel, Panov implicitly suggests that readers need to recalibrate their understanding of the uniform, already known provincial town because, at least in this instance, it functions as the location of a significant mystery which fundamentally undermines any sense of known-ness. Furthermore, this provincial-town location can be read as emphasising, in a self-referential fashion, the fact that knowledge is the novel's primary currency but one that, contrary to expectations generated by this setting, is not easily possessed.

The provincial town of N. in Three Courts also functions as a liminal space full of interpretive potential that is absolutely appropriate to the crime fiction genre. Although the town of $\mathrm{N}$. is the location of the murder and the initial investigation, a significant portion of the crucial action subsequently happens "off-stage" in both St Petersburg and Moscow. For example, the local police in N. are said to put out messages about the crime to the police forces in both of these cities (as well as in Odessa) in case the perpetrator has travelled there; it is the St Petersburg police who manage to capture the dealer trying to offload the diamonds from the stolen tiara; and this man's meetings with the apparent thief (and, the investigator contends, the murderer) are traced to the Hotel Mir in Moscow. In spite of the fact that various of the novel's characters travel between these two cities and N., the reader is never given accurate information about how far N. is actually located from either one - it is just somewhere between the two. This element of spatial organisation can obviously be read mimetically: it is entirely plausible, for instance, that the diamond thief and the dealer operate

of an 1840s Investigator (1869) and Timofeev's Notes of an Investigator are all set either in small villages or in small rural settlements belonging to landowners' estates.

${ }^{9}$ Although in Gogol's Dead Souls the town of N. is described as a typically Russian provincial town, it is likely that its characteristics were inspired by the town of Nizhyn in Ukraine (at that point part of the Russian Empire) where the author attended high school. 
in these bigger, more commercial and more anonymous cities rather than in N. Yet there is also an invitation here to read the position of N., indeterminately located somewhere between Moscow and St Petersburg - with information from these other places repeatedly reported back indirectly -, as a space of potential: the indefinite, liminal nature of the space of $\mathrm{N}$. embodies its potential as a site in which meaning and interpretation can be both generated and interrogated. As such, it functions as an implicit expression of the way in which the investigation into the murder in the novel hovers between states of knowing and not knowing, of mystery and resolution. Just like the town of N., located somewhere between Moscow and St Petersburg, the investigator (and, by extension, the reader) occupy this indeterminate position, suspended between ignorance and knowledge, crime and justice, lies and truth. Moreover, building on Mikhail Epstein's characterisation of the province as a space that is "alienated from itself" (Epstein 1998: 24) ${ }^{10}$ Panov's town of N. is portrayed, at least initially, as being alienated from concepts of truth and justice and the criminal investigator faces a struggle to reconcile the two by solving the crime and holding the perpetrator(s) to account.

\section{The Mansion and its Corridors: Affective Space}

The manner in which Three Courts uses the representation of space to create an affective experience for the reader comes into clearer focus when we consider the more immediate location of the crime: the Ruslanov mansion. The novel opens with the narrator-investigator, Ivan Vasilevich, being informed of Elena's murder by his sidekick, Kokorin, and we then accompany the two men as they travel the short distance from his lodgings to the house which, we are told, has "approximately fifty rooms" (Panov 1876: 15). ${ }^{11}$ The significance of this particular space to the novel is underscored by the fact that Panov dedicates almost the entirety of the first chapter to a description of the mansion's labyrinthine nature as the investigator tries to make his way from the entrance to the crime scene and then on to the victim's body. The reader is informed in considerable detail how, when he enters the family's mansion, Ivan Vasilevich goes up the stairs to the first floor and into the ballroom where many of the guests are still gathered, having been told by the police chief that they are not permitted to leave until he has completed his work. He is then guided by a servant through the ballroom and on through a whole series of other rooms, arranged enfilade, before eventually arriving at a locked door. When this door is opened and they walk through, the men find themselves in an empty room opposite another closed door. The servant informs the detective that this next room is the one in which Elena's body was initially discovered, although it has since been moved. When he walks in, the investigator finds himself in a room with a couch opposite the door, in front of which is kneeling the victim's mother, demanding to know why the police are disturbing the family at such a distressing time. In the walls on either side of the door through which he has entered are two other locked doors and the investigator seems unsure where to go until he is motioned through the door in the right-hand wall by the mother. Once through this door, he finds himself in a corridor at the end of which sits the victim's father, slumped in a chair looking pale. Opposite him is yet another closed

\footnotetext{
${ }^{10}$ Epstein argues that "a province is located, as it were, not in itself; it is alien not in regards to someone or something else, but to itself, inasmuch as its own center has been taken out of itself and transferred to some other space or time" (Epstein 1998: 29-30).

${ }^{11}$ The large country house or manor is, of course, a well-known location for Golden Age British crime fiction, with the work of Agatha Christie featuring numerous such locations, as in The Mysterious Affair at Styles (1920) and And Then There Were None (1940). Prior to this time, it had featured in Arthur Conan Doyle's The Hound of the Baskervilles (1901), and, of course, in a good deal of sensation fiction.
} 
door behind which the narrator eventually finds the victim's bedroom where her body is laying on the bed, covered in blood and with a "repulsive wound" (Panov 1876: 10) on her neck. As if the epistemological challenge posed by the layout of the house to the resolution of the crime was not sufficiently obvious from the terms of this extended description, one of the narrator's first acts after having inspected the immediate crime scene is to order that an architect who is amongst the guests draw up a detailed plan of the entire house as soon as possible. Although this map does not feature directly as a pictorial addition to the narrative (as is the case in some later works), the investigator's request nevertheless underscores the importance of both literal and intellectual mapping to the resolution of the criminal mystery. ${ }^{12}$

It is evidently significant that the novel provides such a detailed account of how the detective has to make his way through an extensive series of rooms, through locked doors and down corridors in order eventually to find the victim's body. Crucially, and in an implicit reflection of the physically bifurcating routes through the house, it represents an exploitation of space that can be interpreted in various ways. The circuitous route that the detective has to take in order to reach Elena's body suggests that the Ruslanov mansion possesses a labyrinthine layout, a feature that clearly signals in the direction both of the Gothic novel of the eighteenth century, with its murderous passions and a general sense of uncanny mystery, and the sensation fiction of the 1860s and the 1870s, such as Mary Elizabeth Braddon's Lady Audley's Secret (1862), in which apparently respectable domestic settings mask complex and scandalous family secrets. The emphasis placed on the series of locked or closed doors that confront the investigator as he makes his way through the space, and which increase the reader's sense of suspense, also references the trope of the locked-room mystery, which appears not only in Poe's "Murders in the Rue Morgue" but also in a number of earlier Gothic novels, such as Horace Walpole's The Castle of Otranto (1764) and Ann Radcliffe's The Mysteries of Udolpho (1794). The locked doors and the circuitous route to the body are clearly intended to function as a structural reflection of the secret feelings and hidden motives that have led to the commission of the crime as well as a foreshadowing of the dead-ends and difficulties that the investigator will encounter in the subsequent stages of the case. However, the labyrinthine nature of the Ruslanov mansion also gestures generically forward into the future as it anticipates the use that Umberto Eco makes of this motif in his postmodern detective novel, The Name of the Rose (1980). ${ }^{13}$ In both Panov and Eco, the physically labyrinthine layout of a building is intended to be interpreted, at least in part, metaphysically, as a reflection on the accessibility of knowledge and truth and crime fiction's effectiveness in interrogating such notions. The spatial organisation indicates that the path to the discovery of the truth of the crime will be anything but a straight one; instead, if indeed it is to be reached, the truth will lie at the end of a series of closed rooms and long, twisting corridors.

Furthermore, the layout of the Ruslanov mansion in Three Courts speaks not only to the mystery involved in the commission of the crime, but also effectively prefigures the detective's ambiguous performance and the difficulties and obstacles he encounters

\footnotetext{
12 There are a number of later works of crime fiction, outside the Russian tradition, that do include drawn maps of the layout of large houses as a complement to the verbal narrative: Agatha Christie's The Murder of Roger Ackroyd (1926), S. S. van Dine's The Greene Murder Case (1928), Ellery Queen's The Tragedy of Y (1932) and Roger Scarlett's Murder among the Angells (1932) are just some examples.

${ }^{13}$ This motif of the labyrinth is also productively exploited by the contemporary Russian crime writer, Boris Akunin, in the third instalment of his Sister Pelagia trilogy, Pelagia and the Red Rooster (2003), with a similar interrogation of the nature of truth and knowledge as is found in Eco.
} 
throughout. Ivan Vasilevich is far from being an interpretive superman in the mould of Poe's Chevalier Dupin: he struggles for a number of months to make any progress through the various clues in the case that themselves mirror the succession of rooms he has had to walk through in the opening chapter. As during his first visit to the mansion, when he tries to resolve the mystery of who has murdered Elena, he is confronted by a number of dead-ends as well as a number of forking paths of interpretation. And just as he has needed to be directed through the house to her body by the servant and her parents, so he is repeatedly in need of a helping interpretive hand in his investigation, either from his sidekick or some other external agent. ${ }^{14}$

Arguably the most crucial aspect of Panov's description of the architecture and layout that the investigator encounters in the Ruslanov mansion is the manner in which elements associated with closure, obfuscation, privacy and mystery simultaneously suggest notions of openness, transparency, the public and (possible) resolution so that the reader remains suspended between these interpretations, in a state of considerable tension. Key to this juxtaposition is the emphasis that Panov places in his mapping of the space of the house on the role of the corridor. As noted above, having walked through a series of interconnected rooms to find the dressing room in which the murder was committed, the detective then leaves this room and enters a corridor that leads him to the bedroom to which Elena's body has been moved. Subsequent descriptions in the novel inform the reader that this corridor runs the length of the Ruslanov mansion between the suite of rooms on one side and the outer wall of the house on the other. This outer wall of the house features a number of windows which look out onto the garden that surrounds the house; more unusually perhaps, the interior wall between the corridor and the rooms also features at least one internal window. The reader is informed that this corridor represents, in accordance with tradition, something of a gallery space as it has numerous portraits adorning its walls, as well as abundant lights. As will be discussed in greater detail below, this same corridor (and the internal and external windows) proves to be of the utmost significance when the detective considers how the murder might have been committed given that all the doors leading into the murder scene were apparently closed.

In a more general context, corridors have significant potential as ambiguous spaces, mediating as they do between the public and the private and functioning historically as a space of contested authority. Prior to the introduction of corridors as an architectural element in the seventeenth century, buildings featured a series of rooms connected directly one to the other and a person's standing could be measured by how far they were permitted to penetrate into that suite of rooms: only the most important would be able to access the most private room at the end. ${ }^{15}$ However, as society became more rigid in its stratification, the desire to keep servants separate from members of the family led to the popularisation of corridors, particularly, but not only, in large family homes. As Rachel Hurdley explains, "corridors are part of a traditional cartography of power, in which both gaze and movement are controlled: palaces and monasteries, government buildings, prisons and hospitals are notable for the socio-political designs of their spatial arrangements" (Hurdley 2010: 49). The corridor's status as a simultaneously public and private space, and one that helps to map power, is

\footnotetext{
${ }^{14}$ In anticipation of remarks to be made later in this article with regard to the novel's representation of windows, Three Courts' emphasis on the series of closed doors also highlights the detective's ambiguous social position as an unwelcome intruder into a privileged household keen to keep its secrets hidden (as indicated by the victim's mother's objection to being disturbed in their grief).

15 See Rachel Hurdley's The Hidden History of the Corridor for BBC Radio 4: https://www.bbc.co.uk/programmes/b095tkgx.
} 
exploited in various ways in Panov's novel. During his interrogation of witnesses regarding the time at the ball before the murder, the investigator learns that this corridor functions, in line with convention, as a public space into which people come to take a break from the dancing and to get some fresh air. Yet, in the section of the corridor that the detective has to traverse between the dressing room that is the crime scene and the bedroom, it assumes the appearance of a potentially more intimate and private space, not least because of the image of the victim's father slumped in a chair at its far end.

Hurdley argues that corridors in general, "constructed as circulation space, simultaneously connect and disconnect other spaces and people in them, making both boundaries against and openings to the outside and outsiders" (Hurdley 2010: 46). With regard to the numerous guests at the ball who appear to circulate relatively freely in this space, the corridor in Panov's novel functions as an opening to the outside: it permits them to escape the stuffiness of the ballroom and take the air; it also demonstrates the family's connection to the town beyond, virtually all of whose inhabitants have been invited to the event. However, when the detective moves through this space, it seems clear that he is cast in the role of the (unwanted) outsider as his presence is only necessary because of the violent consequences of inviting the public into this private house for the ball. Indeed, this status is clearly expressed when the victim's mother asks why the police are in the house at such a difficult time for the family. Moreover, the narrator-investigator's need to walk down the corridor, accompanied by a servant, only to be met by another closed door before he eventually reaches Elena's body emphasises his relative lack of authority as well as the distance that lies between his current position and any eventual resolution to the case. The corridor in the mansion thus functions highly effectively as both literal and metaphysical space, dividing the mansion into public and private, but also suggesting the tension between these two states and the power relations implied by them, a tension experienced by the reader.

Later in the novel, the possibility inherent in the space of the corridor is further exploited as it repeatedly figures in descriptions of the court building during the trial of Nikandr Petrovich Ichalov, an acquaintance of the family who has been identified by the diamond dealer as the man who has tried to sell the stolen diamonds and who has, consequently, been arrested both for theft and for the murder of Elena Ruslanova. Even though this is a public building, Panov again - thanks in large part to his depiction of the corridor - imbues this space with ambiguous meaning where public and private, open and closed, known and unknown collide and are held in tension. Unlike the strict public and professional stratification ensured by the arrangement of the miles of corridors in London's Royal Courts of Justice, opened by Queen Victoria in 1882, the corridors in the town of N.'s court building are a far more heterogeneous space. ${ }^{16}$ On the one hand, the corridors here function as an acutely public space: the reader is told how, on the opening morning of the trial, they are crammed with people all hoping to gain entry to the courtroom to witness proceedings. Not unusually for crime fiction of this era, these people are compared to the crowds queuing up for a theatrical performance: the narrator notes that only the first 150 have been lucky enough to get "tickets" and many of these are armed with opera glasses so as not to miss any detail of the trial. ${ }^{17}$ At this point, and in marked contrast to the corridor's

16 The Royal Courts of Justice have approximately three miles of corridors as part of their construction, arranged strictly by function: the judicial corridor is where judges have their offices; the legal corridor is intended for use by barristers and legal teams; the "unwashed" corridor is for public use; and the fourth, lower corridor has rooms for lawyers and jurors to use during trials. See Hurdley, The Hidden History of the Corridor.

${ }^{17}$ Analogies between criminal investigations / trials and the theatre appeared in the very first work of Russian crime fiction: Sokolovskii's Prison and Life (1866). In the same year, Émile Gaboriau's 
characterisation in the opening chapter, Panov's novel also clearly references the corridor's historical role as a space in which information can circulate. Having been called away on another case on the second day of the trial, when the detective returns to the court building that evening, he heads straight to the corridors in order to ask members of the public their opinion on how the case has gone and what the verdict is likely to be. At the same time, however, this space is also associated with secrecy and continuing mystery. It is while the investigator is in the corridor speaking to people about the trial that he is approached by Elena's best friend, Anna Bobrova, who is dressed all in black, exceedingly pale, and asks him desperately to help her get a seat in the courtroom. The reason for the urgency behind Anna's request is unclear to both the detective and the reader, but the fraught and haunted look in her eyes, as well as the sense of foreboding enhanced by their physical location, suggests that this is a significant moment in the narrative's development.

Subsequent to this point in the novel, the space of the corridor becomes associated with that of the "loggia" within the courtroom itself, as the primarily horizontal organisation of space up until this juncture is superseded by a more vertical arrangement. The corridor and the loggia resemble each other in at least two regards: firstly, both are spaces that the novel links to the notion of the criminal trial as a form of spectacle at which the public seeks entertainment; secondly, they are both described and exploited in terms of their liminality, as spaces that are simultaneously open and closed, connective and obstructive, and linked to both knowledge and truth, but also secrecy. As if to underscore the liminal quality of the space of the loggia, the reader is informed that, although all the seats in this area are actually occupied, when the investigator manages to gain entry for himself and Anna the bailiff orders that a chair be positioned in the aisle between the rows of benches for her to sit on. From this position in the box, Anna is able to observe the judge and jury return to the courtroom in order to pronounce the verdict on Ichalov: guilty. At this point, Three Courts takes a further turn towards generic hybridity as the novel exploits conventions of the fantastic in order to heighten the drama and obfuscate interpretation. The narrator notes that, when the verdict is announced, "someone shuddered next to me" (Panov 1876: 122), the use of the indefinite pronoun promoting a sense of some uncertainty. When he turns around, he sees that Anna has stood up and "with an entirely altered face was looking somewhere vaguely into the distance and trembling all over" (Panov 1876: 122). When the investigator confirms to her that Ichalov has been found guilty, she is said to "scream in some sort of exasperated, desperate and nervous voice" before fainting back onto her chair (Panov 1876: 123). ${ }^{18}$ The president of the court orders her to be removed from the room but, at this point, Anna regains consciousness, gets up from the chair and, significantly in terms of spatial exploitation, approaches the balustrade that separates the loggia from the courtroom. With her dark hair loose and falling on her shoulders in "black waves," making her resemble the heroine of a Gothic novel, Anna announces from this threshold position that she is, in fact, the killer. It is absolutely appropriate that Anna should make her confession from a position that is explicitly identified as being a boundary space: her speech act represents a transition in the novel from secrecy to confession, from cowardice to courage, from innocence to guilt, from an understanding of the crime as having a single culprit to one in which there are dual

novel, Le Crime d'Orcival, contains numerous references to theatre and role-playing, and includes a long explanation by the detective, Monsieur Lecoq, about the similarities between conducting a criminal investigation and writing a play.

${ }^{18}$ As discussed in my monograph, The Fantastic in France and Russia in the Nineteenth Century (2006), such indefinite pronouns, adverbs and adjectives are staple devices of the genre of the fantastic and are employed to render expressions less determinate than they would otherwise be. 
perpetrators, and it signals the close of the first part of the novel before the investigation radically changes course in the second.

\section{The Deceptive Transparency of Glass}

The manner in which Panov's Three Courts uses spatial and architectural features as an implicit expression of its preoccupation with issues related to mystery, knowledge and truth is significantly developed by the ambiguity it generates around images of glass and windows. The balance that crime fiction continually needs to strike between progress towards a resolution of the criminal mystery and retardation along that same path is effectively figured in the way that Panov combines references to the labyrinthine nature of the mansion with an illustration of its expansive use of glass. However, the intention behind that use of glass is far from being monosemic. For instance, as the detective arrives at the Ruslanov mansion for the first time, it is notably the windows of the house that attract his attention. He remarks that bright light spills out of the large windows on the second floor and that many of the guests at the ball have their faces pressed up against the glass, apparently awaiting his arrival. This early image articulates the various matrices of power that are at play in the novel: it simultaneously creates an impression of the Ruslanov family's socio-economic privilege which is shown, nevertheless, to be no protection against murderous violence and grief; it suggests the importance of the house's façade in terms of both architecture and social standing (and which, according to Lounsbery, has particular currency in the context of the provincial town); and, particularly in the image of the various faces staring out, it captures the adversarial nature of the detective's challenge. Although the transparency of glass may often appear to "affirm connection," when used in a window it may equally "assert exclusion" (Beer 2011: 3). Here, the mansion's windows certainly suggest the narrator's exclusion from the provincial town's social circle (indeed, one might ask why he does not figure amongst the 227 invitees to the ball), but they can also be seen to represent in visual terms the task that awaits him of trying to penetrate to the heart of the murder mystery. In epistemological terms, the windows here both announce the possible access to knowledge upon which so much crime fiction is predicated and hint at the barriers that lie between the detective and the discovery of the truth of the crime.

The manner in which Panov deploys images of glass and windows in Three Courts is central to the novel's self-reflexive consideration of the performance of the narrator-detective and, by implication, the role of the reader in texts belonging to this genre. In this respect, it recalls Poe's "Murders in the Rue Morgue" where the locked-room mystery of the L'Esplanaye murders is shown, thanks to Dupin's discovery of the loose nails in the window frames, to be a deception because the apartment is actually an open, interconnected space rather than an hermetically sealed one. In a similar fashion to "Murders in the Rue Morgue," Panov's Three Courts provides an exemplary illustration of Julia Bekman Chadaga's claim that, in Russian texts from the eighteenth century onwards, glass "acts as a text to be read" (Bekman Chadaga 2014: 18). In the specific context of crime fiction, glass and windows function by extension as clues that need to be deciphered. So, for instance, as the investigator tries to find the victim's body, and is in the room where the murder was committed and where Elena's mother is kneeling by the couch, he notes that, although there are no external windows in the room, it is lit during the daytime by means of a glass ceiling. Even at its first mention, this architectural feature strikes the reader as somewhat unusual and its role in the narrative proves to be repeatedly linked to problems of interpretation. As the investigation proceeds, it serves as a clue imbued with particular significance and is one over which the investigator spends a considerable amount of time and effort. As its transparent, illuminating 
nature suggests, this ceiling initially appears to represent a possible solution to the mystery as the detective surmises that it could have been used by the murderer to access the room unseen. However, the deceptive nature of its transparency (and readability) is mooted by the fact that it is attached to an attic space in which the murderer could have remained hidden during the ball until the moment of the crime. In actual fact, this glass ceiling is an architectural feature used to reveal the faultiness of the investigator's reading because not only is it ultimately shown to have played little or no part in the crime, it also distracts him from the far more important glass text in the room that he ought to be attempting to decipher.

Although, as has been noted, this room has no external windows, behind the couch where her mother is kneeling as the detective arrives and where Elena was apparently sitting when she was attacked is an internal window. We are informed that this window gives out into the corridor down which the detective will later walk and opposite it is another window in the external wall of the house which looks out onto the garden. It is only after he has interrogated a great many witnesses, some of whom note that both the internal and external windows were open before the murder, that the detective comes to understand their potential significance. However, what he struggles with in his deliberations about their role in the crime is the seeming contradiction between their transparency and the apparent invisibility of the murderer. Although a ladder leaning up outside the external window clearly suggests that this window has played some role in the crime, the detective finds it difficult to understand how the killer could have passed through it, across the corridor and through the internal window without being seen by the scores of guests present. Here, then, glass is shown not to render visible and "known" in the way that the detective and the reader might expect but rather to obfuscate in much the same way as the labyrinthine layout of the mansion does. In fact, at this point, Three Courts skilfully exploits the tensions inherent between public / private, known / unknown, and visible / invisible in the image of both the window and the corridor as the detective struggles to comprehend how the killer could have remained unseen and unknown whilst entering and traversing such apparently open and transparent spaces. Panov appears to be underscoring the dangers of attempting to draw an easy equation between transparency and visibility on the one hand and, on the other, knowledge about the truth of the crime. The detective's failure to correctly read the windows in the crime scene at the first attempt functions as an eloquent anticipation of his subsequent failure to look beyond the initially visible perpetrator, Ichalov, who has attempted to sell the stolen diamonds, to the hidden killer, Anna, who lurks behind him. Indeed, the physical arrangement of the windows at this point in the novel (with the internal window somehow mirrored or framed by the external window and the corridor in between) is emblematic of many aspects of the novel's internal narrative organisation. Just as Anna has lurked in the corridor and then leaned through the internal window from behind Elena to slit her throat, so she spends the entirety of the first part of the novel hiding behind the figure of Ichalov, allowing him to be convicted of the murder.

Having unmasked herself from the liminal position at the balustrade in the courtroom loggia, in Part Two of the novel Anna finds herself in the unusual position of having to prove her guilt rather than her innocence. The sense of events being refracted through a different "window" is strong here as the investigator's initial resolution of the crime has to be recalibrated to take account of Anna's confession and guilt. In this second part, readers find themselves in a position akin to the liminal space of the corridor, framed by two windows, making connections between Anna's new account of the crime (which unquestionably proves her guilt) and the first version of events presented by the narrator-detective. The sense created by the depiction of the arrangement and the role of the windows in Three Courts, reflected or refracted as it is in the organisation of the novel's plot in its two parts, brings to mind 
Schmid's contention that "space in crime fiction is rhizomatic in the Deleuzian sense" (Schmid 2012: 10). The manner in which Panov describes not just the windows, but also the corridor and the arrangements of the rooms and other spaces in the novel, makes clear that, in spite of initial appearances, they are not actually separate spaces, but rather a network of interconnected spaces that need to be read as functioning in concert with each other. In fact, this image of interconnectedness and communication is one that extends beyond the depiction of space in this and other crime novels to be applicable to the genre more generally. Just as one space is linked to another space in Three Courts, and the second part of the novel insists on a re-reading of the first, so the genre of crime fiction is not only constituted of texts in conversation with one another, but, as whole, functions in dialogue with other genres and modes.

\section{Conclusion}

Panov's depiction of glass and windows is typical of the ambiguous status granted to many of the spatial elements in Three Courts. On the one hand, the setting in the provincial town, the layout of the many-roomed mansion and the presence of so much glass within it can all be read as mimetic descriptions of a recognisable extrafictional reality. Russian crime writers in the late Imperial era wrote in the realist mode that was dominant at the time and their realist ends were in part achieved by means of a mimetic description of the spatial setting of their works, whether the urban geography of St Petersburg in Dostoevskii's Crime and Punishment or the provincial town featured in Panov's works. On the other hand, however, Three Courts is a work that provides further proof of the claim made by Philip Howell, and other critics, that this realist epistemology carries an ideological significance, especially with regard to its implicit suggestion as to the knowability of the world (Howell 1998: 359). In Three Courts, space is never just a setting that should be taken literally: like so many other crime fiction writers of this era and subsequent ones, in Russia and in all other national traditions, Panov ensures that space also has a symbolic or metaphorical value. For instance, the manner in which the novel depicts the detective moving through the space of the Ruslanov mansion, plays a significant role in his characterisation as a flawed investigator prone to taking wrong turns and coming up against dead-ends. Moreover, all of the spaces of the novel discussed here ambiguously negotiate conventional boundaries between values such as open / closed, public / private, visible / invisible, known / unknown. As such, these spaces promote a sense of themselves as functioning self-referentially to offer up an interrogation of the nature of knowledge and the possibility of ever actually arriving at a single, definitive truth. The spaces in Panov's Three Courts present themselves as texts to be read whilst simultaneously indicating the difficulties encountered in arriving at a straightforward, monosemic reading of them.

\section{Bibliography}

Beer, Gillian. 2011. "Windows: Looking In, Looking Out, Breaking Through." In Thinking on Thresholds: The Poetics of Transitive Spaces, edited by Subha Mukherji, 3-16. London: Anthem Press.

Brooks, Jeffrey. 2003. When Russia Learned to Read: Literacy and Popular Culture 1861-1917, Evanston, IL: Northwestern University Press.

Burnham, William. 2002. "The Legal Context and Contributions of Dostoevsky's Crime and Punishment." Michigan Law Review, 100.6: 1227-48. 
Chadaga, Julia Bekman. 2014. Optical Play: Glass, Vision and Spectacle in Russian Culture. Evanston, IL: Northwestern University Press.

Epstein, Mikhail. 1998. The God of Details: The Folk Soul and Private Life in Russia at the End of the Empire. Moscow: Elinina.

Howell, Philip. 1998. "Crime and the City Solution: Crime Fiction, Urban Knowledge and Radical Geography." Antipode, 30.4: 357-78.

Hurdley, Rachel, 2017. The Hidden History of the Corridor. Juniper/ BBC Radio 4. https://www.bbc.co.uk/programmes/b095tkgx. Accessed 22 December 2019.

Hurdley, Rachel. 2010. "The Power of Corridors: Connecting Doors, Mobilising Materials, Plotting Openness." The Sociological Review, 58.1: 45-64.

Lounsbery, Anne. 2004. “'To Moscow, I Beg You!’: Chekhov's Vision of the Russian Provinces.” Toronto Slavic Quarterly. http://sites.utoronto.ca/tsq/09/lounsbery09.shtml. Accessed 22 December 2019.

McReynolds, Louise. 2006. “'Who Cares Who Killed Ivan Ivanovich': The Literary Detective in Tsarist Russia." Russian History, 36: 391-406.

Panov, S. A. 1876. Three Courts, or Murder during the Ball: The Tale of a Judicial Investigator in Two Parts. St Petersburg: Skariatin.

Reitblat, Avram. 2009. From Bova to Bal'mont and Other Works on the Historical Sociology of Russian Literature. Moscow: Novoe literaturnoe obozrenie.

Schmid, David. 2012. "From the Locked Room to the Globe: Space in Crime Fiction." In CrossCultural Connections in Crime Fiction, edited by V. Miller et al., 7-23. London: Palgrave Macmillan.

Whitehead, Claire. 2006. The Fantastic in France and Russia in the Nineteenth Century: In Pursuit of Hesitation. Oxford: Legenda.

Whitehead, Claire. 2018. The Poetics of Early Russian Crime Fiction 1860-1917: Deciphering Stories of Detection. Oxford: Legenda. 